Sains Malaysiana 48(6)(2019): 1179-1185

http://dx.doi.org/10.17576/jsm-2019-4806-04

\title{
High Sensitivity Au-based Kretschmann Surface Plasmon Resonance Sensor for Urea Detection
}

(Sensor Resonans Plasmon Permukaan Kretschmann berasaskan Au Berkepekaan Tinggi untuk Pengesanan Urea)

\author{
P. Susthitha Menon*, Fairus Atida Said, Gan Siew Mei, Mohd Ambri Mohamed, Ahmad RifQi Md Zain, \\ SAHBUDIN SHAARI \& BURHANUDDIN YEOP MAJLIS
}

\begin{abstract}
Kretschmann-based Surface Plasmon Resonance (SPR) optical sensor was applied to detect the presence of kidney wastes such as urea in solutions. To enhance the sensitivity of the SPR sensor, nanolaminated gold film (thickness of $50 \mathrm{~nm}$ ) was used. In this work, the SPR response to urea in various concentrations were measured and investigated using optical wavelengths of $670 \mathrm{~nm}$ and $785 \mathrm{~nm}$. The signals were compared between pure urea solution versus mixed solution in the presence of the 0.227 umol urease enzyme. The proposed mixed solution is to eliminate doping and gel entrapment process for enzyme immobilization in conventional method. Angular interrogation technique was used to measure the sensor performance in urea detection using pure and mixed solutions with urea concentration of $0-800$ mM. Upon exposure to mixed solution using $785 \mathrm{~nm}$ optical wavelength, the nanolaminated gold film exhibited higher SPR sensitivity as much as $7.8 \mathrm{M}^{-1}$ than a pure urea solution $\left(1.4 \mathrm{M}^{-1}\right)$. The coupling activity between urea and urease molecules in the mixed solution near the nanolaminated gold film surface lead to sensitivity enhancement. Angle shifting of mixed solution on $50 \mathrm{~nm}$-thick nanolaminated gold film using $670 \mathrm{~nm}$ optical wavelength was greater by 50\% compared to $785 \mathrm{~nm}$. Sensorgram data shows a steady and linear increment in SPR incident angle shifting when urea concentration increased. To the best of our knowledge, this is the first time that Kretschmann-based SPR has been used for urea sensing at 670 $\mathrm{nm}$ and $785 \mathrm{~nm}$ optical wavelengths.
\end{abstract}

Keywords: Nanolaminated gold film; surface plasmon resonance; urea; urease enzyme

\section{ABSTRAK}

Biosensor optik resonans plasmon permukaan (SPR) yang berasaskan Kretschmann digunakan untuk mengesan kehadiran bahan buangan buah pinggang seperti urea dalam larutan. Bagi meningkatkan kepekaan sensor SPR, filem emas nanolaminasi (ketebalan $50 \mathrm{~nm}$ ) telah digunakan. Dalam kertas ini, tindak balas SPR terhadap urea dalam pelbagai kepekatan diukur dan dikaji menggunakan panjang gelombang optik $670 \mathrm{~nm}$ dan $785 \mathrm{~nm}$. Isyarat yang diperoleh dibandingkan antara larutan urea tulen dan campuran larutan urea dan urease $(0.227 \mu m o l)$. Campuran larutan yang dicadangkan adalah untuk mengantikan kaedah konvensional seperti proses pengedopan dan pemerangkapan gel untuk pemegunan enzim. Teknik pemisitan sudut digunakan untuk mengukur prestasi sensor dalam pengesanan urea menggunakan larutan urea tulen dan campuran larutan urea/urease dengan kepekatan urea 0-800 mM. Apabila didedahkan kepada larutan campuran urea/urease menggunakan panjang gelombang optik $785 \mathrm{~nm}$, filem emas nanolaminasi menunjukkan sensitiviti SPR yang lebih tinggi sebanyak $7.8 \mathrm{M}^{-1}$ berbanding larutan urea tulen (1.4 $\left.M^{-1}\right)$. Aktiviti pengandingan antara molekul urea dan urease berhampiran permukaan filem emas nanolaminasi boleh dikaitkan dengan peningkatan sensitiviti sensor. Anjakan sudut resonans campuran larutan urea/urease pada filem emas nanolaminasi $50 \mathrm{~nm}$ dengan menggunakan panjang gelombang optik $670 \mathrm{~nm}$ lebih besar sebanyak $50 \%$ berbanding dengan $785 \mathrm{~nm}$. Data sensorgram menunjukkan kenaikan mantap dan linear dalam anjakan sudut resoanans SPR apabila kepekatan urea meningkat. Ini merupakan kali pertama SPR yang berasaskan Kretschamnn telah digunakan untuk sensor urea menggunakan panjang gelombang optik $670 \mathrm{~nm}$ dan $785 \mathrm{~nm}$.

Kata kunci: Enzim urease; filem emas nanolaminas; resonans plasmon permukaan; urea

\section{INTRODUCTION}

Kidney plays an important role in filtering waste materials from the foods, medications, and toxic substances for maintaining human health. High level of urea, for example, may indicate kidney failure. The normal level of urea in human body is between 3-7 mM. Urea concentration in the range of $30-80 \mathrm{mM}$ indicate kidney malfunction. At above $30 \mathrm{mM}$, hemodialysis treatment is required whereas at above $50 \mathrm{mM}$ the organ is damaging (Mahadeva \& Kim 2013). Thus, the measurement of urea concentration is crucial to diagnose such disease.

Meanwhile, in an effort to develop an artificial kidney, optical sensing method such as surface plasmon resonance (SPR) provides an excellent way to detect kidney wastes 
and to measure the biomolecular interaction in real-time and label-free mode. The SPR is a surface-sensitive optical phenomenon where an electro-magnetic wave propagates along the surface of a thin metal layer. Excitation of surface plasmon is required to get the resonance oscillation. It is based on the total internal reflection at the metal-dielectric interface. The excitation of surface plasmon (SP) can be accompanied either by varying the incidence angle (angular interrogation) or by varying the wavelength (wavelength interrogation) of the optical laser beam. In SPR sensors with angular modulation, various wavelengths of monochromatic light source can be utilized for illumination. The commonly used technique for plasmon excitation in angular modulation mode is the Kretschmann configuration where the monochromatic light source passes through a prism and subsequently undergo total internal reflection to excite plasmon on the metal surface. The SPR is represented by a sharp dip in resonance curve which corresponds to the minimum reflectivity. The monitoring of biomolecular interactions can be made by measuring the shift at resonance angle as the refractive index near the sensing medium changed (Verma \& Gupta 2014). Wide studies of analyte-ligand interactions have been performed on functionalized surfaces with a variety of biomolecules such as protein, ribonucleic acid (RNA) and deoxyribonucleic acid (DNA). Today, various kinds of SPRbased sensor designs have been proposed because it is an attractive technique to sense environmental pollutants and medical diagnosis.

In 1983, Liedberg et al. first reported the SPR sensing method for gas detection. Recently, the urea sensing and detection research has received great attention. Various techniques for urea detection have been reported in the literature such as SPR-based optical fiber (Verma \& Gupta 2014), nonenzymatic piezoelectric sensor (Yang et al. 2015), surface enhance raman scattering (Han et al. 2012), Z-scan technique (Dhinaa \& Palanisamy 2010), on-site microfluidic system (Yang et al. 2014), and ion sensitive field effect transistors (Premanode \& Toumazou 2007). Verma and Gupta (2014) investigated concentration of urea in the range of $0-180 \mathrm{mM}$ on urease enzyme immobilized gel layer over silver and silicon on top of uncladed optical fiber-based SPR sensor using wavelength interrogation technique. The sensor gave $8.51 \mathrm{~nm}$ total shifts in incident wavelength for $0-180 \mathrm{mM}$ urea concentration in a sample. Yang et al. (2015) presented method to detect urea in concentration from 0.1 to $10.0 \mathrm{mM}$ using enzyme-doped thread with polyvinylchloride (PVC) membrane coating for on-situ urea detection. In these methods, enzyme immobilization on numerous solid supports, such as enzyme doping tread and gel entrapment method, is required to increase urease stability. However, one of the potential drawbacks of immobilization is that although it increases longevity, there is typically also a decrease in the activity of the enzyme. This can arise from changes in the conformational state of the enzyme that affect the active site.

Herein, a proposed SPR sensor using Krestchmann configuration with urea and urease enzyme mixture offers an economical, label-free detection method for ease of operation, excellent sensitivity and rapid selectivity towards the target analyte (Gan et al. 2018; Jamil et al. 2018). We analysed the presence of kidney wastes such as urea at concentrations $0-800 \mathrm{mM}$ in enzymatic and non-enzymatic solution using optical wavelengths of 670 $\mathrm{nm}$ and $785 \mathrm{~nm}$. This work explores the early stages in designing SPR-based sensors for medical exploration in artificial kidney deterioration before the knowledge is subsequently employed in optical fiber-based SPR sensor for portable and cost-effective applications.

\section{EXPERIMENTAL METHOD}

The urea and urease enzyme (type III Jack Beans) were obtained from Sigma Aldrich and were all used as purchased. Ultrapure water was from Milipore ${ }^{\circledR}$ system (resistivity of $18.2 \mathrm{M} \Omega . \mathrm{cm}$ at room temperature of $25^{\circ} \mathrm{C}$ ). SPR curves were recorded on a SPR Navi 200 instrument (BioNavis Ltd.). Sensor slide of $50 \mathrm{~nm}$-thick nanolaminated gold film coated on a $0.55 \mathrm{~mm}$-thick solid-lime float glass slide was purchased from BioNavis Ltd. (Finland).

Prior to experiment, urea and urease solutions of desired concentrations were prepared. For preparing urea solution, stock solution of $800 \mathrm{mM}$ was first prepared by dissolving $0.96 \mathrm{~g}$ of urea in $20 \mathrm{~mL}$ ultrapure water in a test tube with occasional stirring. Next, a serial dilution was made as follows; $10 \mathrm{~mL}$ of $800 \mathrm{mM}$ stock solution was added to $10 \mathrm{~mL}$ of ultrapure water and stirred well to obtain urea of $400 \mathrm{mM}$. Similarly, $10 \mathrm{~mL}$ of the $400 \mathrm{mM}$ stock solution was taken and added to $10 \mathrm{~mL}$ of ultrapure water with occasional stirring to obtain the urea solution at $200 \mathrm{mM}$. This step was repeated to finally obtained a series of urea solution at concentration 50, 100, 200, 400 , and $800 \mathrm{mM}$. On the other hand, urease solution was prepared by adding $0.5 \mathrm{~g}$ of urease and $50 \mathrm{~mL}$ of cold ultrapure water into a test tube. The mixture was shaken occasionally to obtain a completely dissolved enzyme solution at $0.227 \mu \mathrm{mol}$. It should be noted that the urease enzyme solution was prepared just prior to SPR sensing because it denatured easily under room temperature.

The SPR Navi 200 instrument used was based on the Kretschmann configuration where incident light was coupled via prism to enhance the wave vector of the incident light to match with that of the surface plasmon (Figure 1). The instrument enabled real-time observation without labelling of analyte structure, in both wet and dry states. SPR was excited by a p-polarized light (TM mode). The $50 \mathrm{~nm}$-thick nanolaminated gold film sensor slide was used for investigating SPR responds to urea and urea/urease solutions at $670 \mathrm{~nm}$ and $785 \mathrm{~nm}$ optical wavelengths. Firstly, the peristaltic pump on the BioNavis instrument was turned on in order to fill the flow cells with ultrapure water (as a buffer) at $100 \mu \mathrm{L} / \mathrm{min}$ flow rate. Once the buffer reached the nanolaminated gold film sensor, urea solution at $50 \mathrm{mM}(0.5 \mathrm{~mL})$ was injected using a syringe, keeping the injection valve in the 'inject' 
position for $2 \mathrm{~min}$, before turning off the injection valve for another $2 \mathrm{~min}$ to allow the buffer solution flown through the flow cell onto the nanolaminated gold film. These steps were repeated for urea of 100, 200, 400 and $800 \mathrm{mM}$ concentrations. As for the urea/urease solution, urease enzyme solution $(1 \mathrm{~mL})$ was mixed with $50 \mathrm{mM}$ urea solution $(1 \mathrm{~mL})$ before injected into the injection valve. Likewise, this step was repeated for urea of 100 , 200,400 , and $800 \mathrm{mM}$ concentrations. As the refractive index at the sensing region changed due to increase in urea concentration, shift in resonance angle were recorded in SPR spectra. Sensorgram, linearity, repeatability and sensitivity analyses of the $50 \mathrm{~nm}$-thick nanolaminated gold film sensor for urea detection were investigated based on the SPR spectra obtained (Menon et al. 2018; Said et al. 2017).

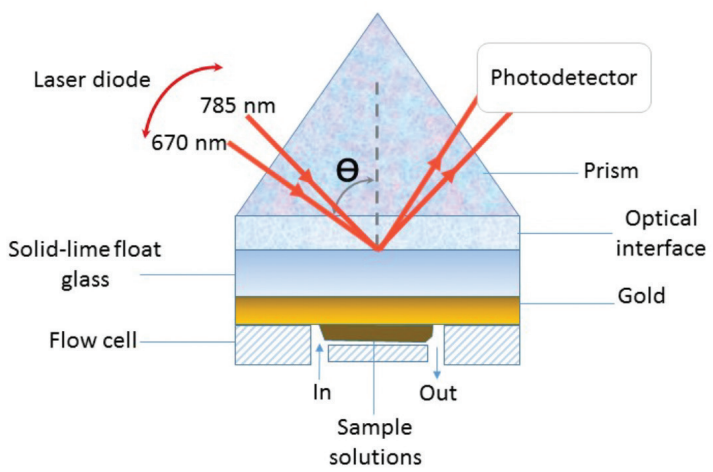

FIGURE 1. SPR Kretschmann configuration measurement setup
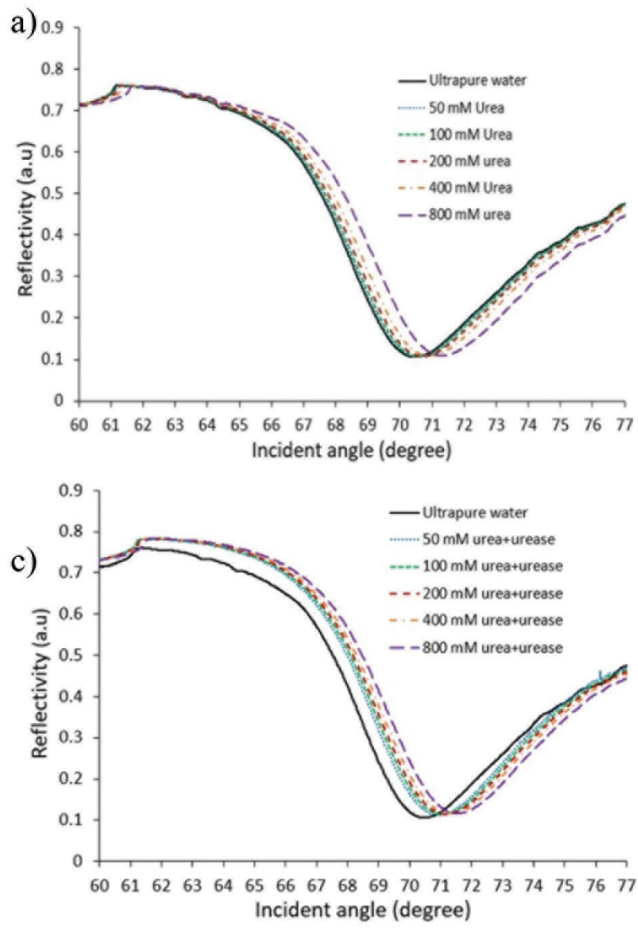

\section{RESULTS AND DISCUSSION}

Experimental investigation was conducted on the $50 \mathrm{~nm}$ thick nanolaminated gold film sensor for a series of urea concentration in pure and mixed solutions using $670 \mathrm{~nm}$ and $785 \mathrm{~nm}$ optical wavelengths. Figure 2(a) and 2(b) depicts the SPR spectra of the sensor towards ultrapure water and urea solution at different concentrations. When exposed to an increased urea concentration (50- $800 \mathrm{mM}$ ), the nanolaminated gold sensor showed an increase in the resonance angle of the incident light. Ultrapure water (buffer solution) was used to obtain the baseline and the minimum reflectance occurred at $70.5^{\circ}$ and $66.87^{\circ}$ angle at $670 \mathrm{~nm}$ and $785 \mathrm{~nm}$ optical wavelengths, respectively. The resonance angle shifted to the right $\left(70.57^{\circ}\right)$ and $\left(66.92^{\circ}\right)$ when exposed to $50 \mathrm{mM}$ urea at $670 \mathrm{~nm}$ and $785 \mathrm{~nm}$, respectively. These responses are equivalent to a change of $0.07^{\circ}$ and $0.05^{\circ}$ in the resonance angle from the baseline. As shown in Figure 2(c) and 2(d), the resonance angle shifted even more when the sensor was exposed to a mixture of 1 $\mathrm{mL}$ of $50 \mathrm{mM}$ urea with $1 \mathrm{~mL}$ of urease enzyme solution; $0.39^{\circ}$ at $670 \mathrm{~nm}$ and $0.25^{\circ}$ at $785 \mathrm{~nm}$ optical wavelength, respectively. This was due to the enzymatic reaction that changed both the real and imaginary parts of the refractive index of the sensing region (Verma \& Gupta 2014). Hence, the SPR response curve obtained indicated that the $50 \mathrm{~nm}$ thick nanolaminated gold sensor was very sensitive to the urea/urease mixed solutions.

In order to observe the SPR responses in a clearer manner, a sensorgram of the resonance angle shift in the function of time for various urea concentrations and

b)
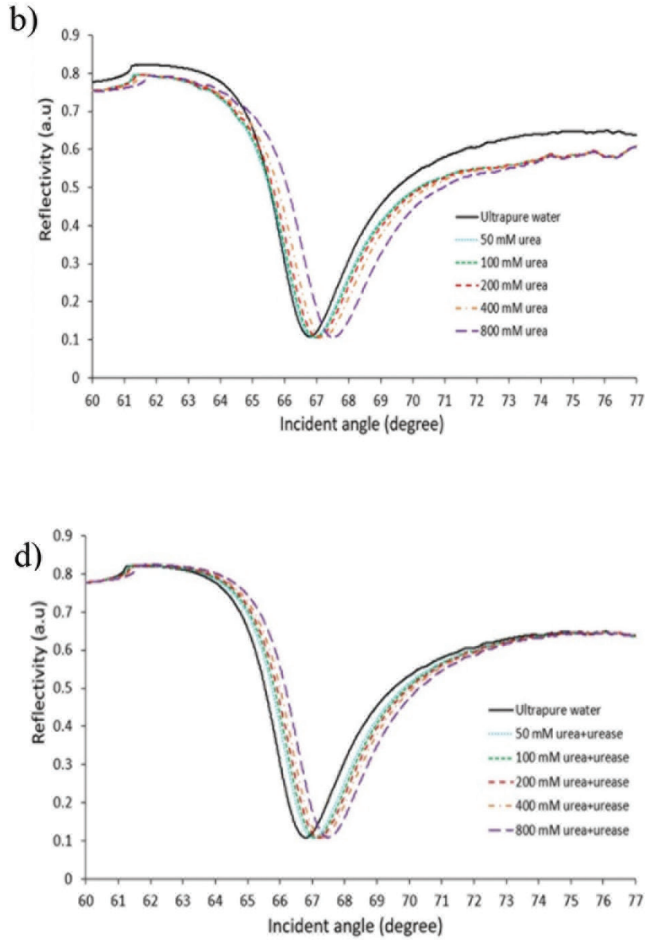

FIGURE 2. SPR curves of $50 \mathrm{~nm}$-thick nanolaminated gold exposed to urea and mixture of urea/urease solutions with different concentration using (a, b) $670 \mathrm{~nm}$ and (c, d) $785 \mathrm{~nm}$ 
optical wavelength was plotted as depicted in Figure 3. The curve shows the 'on-off' nature of the sensor when the nanolaminated gold film was exposed to buffer solution, urea, and urea/urease solutions. Upon exposure to light at $670 \mathrm{~nm}$ for urea solutions of 50, 100, 200, 400 and 800 $\mathrm{mM}$ concentrations, the resonance angle increased as much as $0.07^{\circ}, 0.13^{\circ}, 0.24^{\circ}, 0.43^{\circ}$ and $0.83^{\circ}$, respectively. At $785 \mathrm{~nm}$ wavelength, the resonance angle increased $0.05^{\circ}, 0.1^{\circ}, 0.19^{\circ}, 0.34^{\circ}$ and $0.66^{\circ}$, respectively. On the other hand, upon exposure to light at $670 \mathrm{~nm}$, the urea/ urease solution with urea concentrations of 50, 100, 200, 400 and $800 \mathrm{mM}$, the resonance angle increased $0.39^{\circ}$, $0.49^{\circ}, 0.6^{\circ}, 0.75^{\circ}$ and $0.98^{\circ}$, respectively, whereas at 785 $\mathrm{nm}$ wavelength, the resonance angle increased $0.25^{\circ}, 0.32^{\circ}$, $0.4^{\circ}, 0.52^{\circ}$ and $0.7^{\circ}$, respectively. The results showed that SPR response on the nanolaminated gold film exposed to a mixed solution displayed a higher incident angle shift which corresponds to a higher sensitivity compared to the pure urea solution for all urea concentrations. The slight difference in the incident angle of the buffer solution (baseline) was expected due to sub-nanometer changes in the thickness of nanolaminated gold film layer. The sensorgram shows that the sensor was able to respond promptly and continuously, indicating the stability of the equipment and the capability of nanolaminated gold film to detect different concentrations of urea with or without the presence of the urease enzyme.

Table 1 illustrates the summary of sensitivity and incident angle of proposed sensor towards various urea concentrations in pure urea and urea/urease mixed solution. Incident angle of SPR curve increased with the increased in urea concentration for both solutions using $670 \mathrm{~nm}$ and 785 $\mathrm{nm}$ optical wavelength. Sensitivity is defined as the shift in incident angle per unit change in the urea concentration. For the $50 \mathrm{mM}$ pure urea solution, the sensitivity obtained was $1.4 \mathrm{M}^{-1}(670 \mathrm{~nm})$ and $1 \mathrm{M}^{-1}(785 \mathrm{~nm})$, respectively, as in Figure 4. While for the same urea concentration in mixed solution, a higher sensitivity of $7.8 \mathrm{M}^{-1}(670 \mathrm{~nm})$ and $5 \mathrm{M}^{-1}(785 \mathrm{~nm})$ were achieved, which about five to seven times higher than results obtained for pure urea solution. This may be the results of coupling activity between urea and urease increaseing the refractive index of the sensing surface and leading to the increase in the incident angle shift. However, saturation limit was observed at higher concentrations of urea. The decrease in angle shifting (sensitivity) possibly occurred due to the limited quantity of urease enzyme at higher concentrations of urea. The urease enzyme catalyses the hydrolysis of urea which

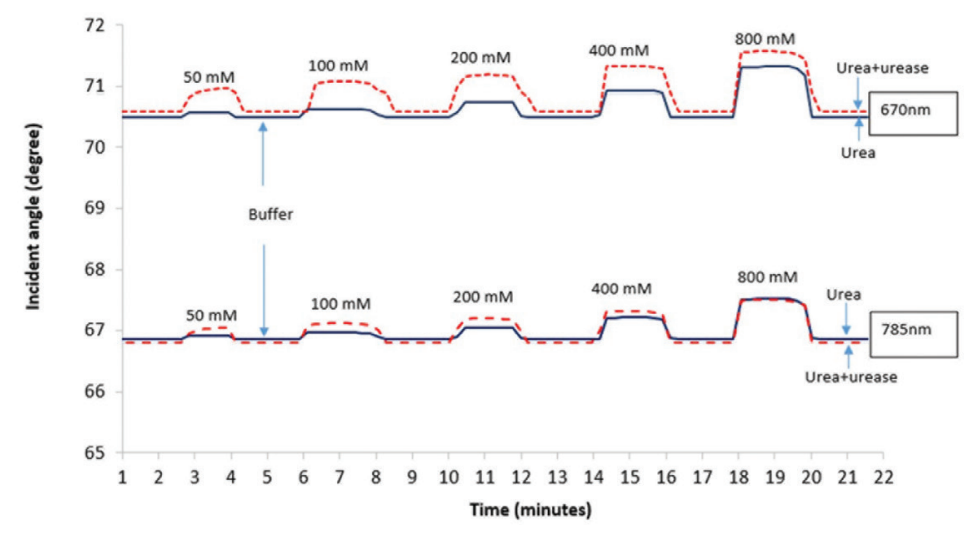

FIGURE 3. Sensorgram of $50 \mathrm{~nm}$-thick nanolaminated gold exposed to pure urea versus mixed urea/urease solutions with different concentrations $(0-800 \mathrm{mM})$ using $670 \mathrm{~nm}$ and $785 \mathrm{~nm}$

TABLE 1. Summary of sensitivity and incident angle of $50 \mathrm{~nm}$-thick nanolaminated gold exposed to pure urea solution and mixed solution with various urea concentration

\begin{tabular}{lccccc}
\hline & $\begin{array}{c}\text { Urea } \\
\text { concentration } \\
(\mathrm{mM})\end{array}$ & \multicolumn{2}{c}{$670 \mathrm{~nm}$ optical wavelength } & \multicolumn{2}{c}{$785 \mathrm{~nm}$ optical wavelength } \\
\cline { 3 - 5 } & 50 & Sensitivity $\left(\mathrm{M}^{-1}\right)$ & Incident angle $\left(^{\circ}\right)$ & Sensitivity $\left(\mathrm{M}^{-1}\right)$ & Incident angle $\left(^{\circ}\right)$ \\
\hline \multirow{3}{*}{ Pure urea solution } & 100 & 1.4 & 70.57 & 1.0 & 66.92 \\
& 200 & 1.3 & 70.63 & 1.0 & 66.97 \\
& 400 & 1.2 & 70.74 & 0.95 & 67.06 \\
& 800 & 1.0375 & 70.93 & 0.85 & 67.21 \\
Mixed urea/urease & 50 & 7.8 & 71.33 & 0.825 & 67.53 \\
solution & 100 & 4.9 & 70.98 & 3.0 & 67.05 \\
& 200 & 3.0 & 71.08 & 2.0 & 67.12 \\
& 400 & 1.875 & 71.34 & 1.3 & 67.20 \\
\end{tabular}




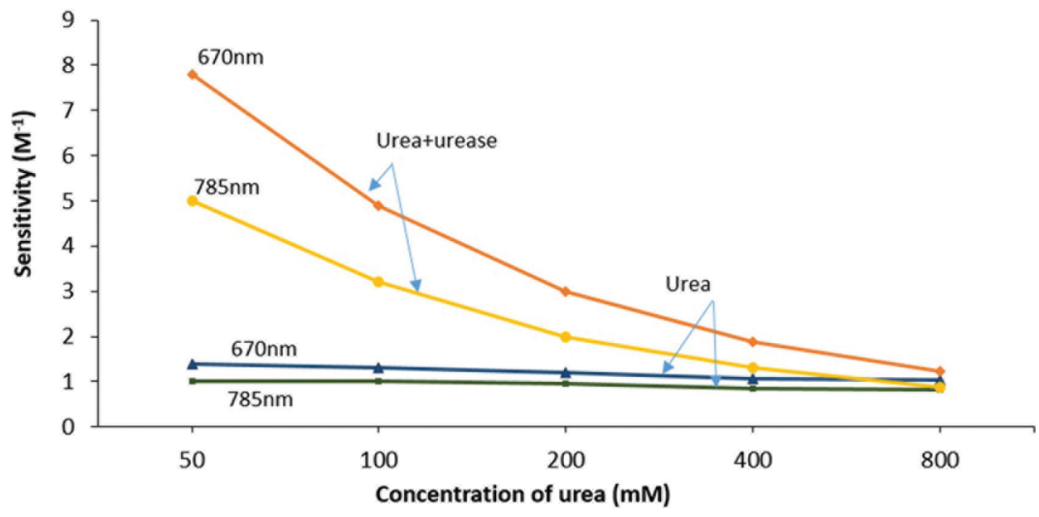

FIGURE 4. Sensitivity trend of $50 \mathrm{~nm}$-thick nanolaminated gold exposed to urea and mixture of urea/urease solution with different concentration $(0-800 \mathrm{mM})$ using $670 \mathrm{~nm}$ and $785 \mathrm{~nm}$

then produced ammonia and carbon dioxide, therefore, a lack of this enzyme for higher urea concentrations causes decrease of urease activity which in turn limit the sensor sensitivity. For the pure urea solution, the sensitivity trend almost flattens out from $50 \mathrm{mM}$ to $800 \mathrm{mM}$ (linear). Hence, it can be concluded that the urease enzyme enhances the sensitivity of the nanolaminated gold film SPR sensor.

Figure 5 shows a linear relationship between SPR angle shifting and the urea concentration in the range 50-800 $\mathrm{mM}$. Pure urea solution on nanolaminated gold shows highest linearity of 0.998 in both optical wavelengths followed by 0.826 and 0.779 linearity obtained by mixed solutions in $785 \mathrm{~nm}$ and $670 \mathrm{~nm}$ wavelength, respectively. This is possibly due to limited urease enzyme at certain level of urea concentration and is in agreement with the discussion in Figure 4.

Figure 6 shows the SPR angle shifting ploted as a function of urea concentrations from $50 \mathrm{mM}$ to 800 $\mathrm{mM}$ on $50 \mathrm{~nm}$-thick nanolaminated gold film. The error bar indicates the minimum and maximum deviations of the SPR angle shifting when exposed to different concentrations of urea solutions. The angle shifting had increased from $50 \mathrm{mM}$ to $800 \mathrm{mM}$, however, the magnitude of the error bars increases with higher urea concentration. It is not synchronized in every concentration and represent moderate performance of repeatibility at higher urea concentration. The average standard deviation relative to the mean angle shifting for a pure urea solution is $\pm 8.24 \%$ and $\pm 4.79 \%$ using $670 \mathrm{~nm}$ and $785 \mathrm{~nm}$ optical wavelength, respectively. Meanwhile, for the mixture of urea/urease solution, the average standard deviation relative to mean angle shifting was $\pm 4.51 \%$ and $\pm 5.02 \%$ using $670 \mathrm{~nm}$ and $785 \mathrm{~nm}$ optical wavelength, respectively, which is almost two times smaller than that obtained by the sensor with a pure urea solution for the $670 \mathrm{~nm}$ wavelength. The results of low standard deviation obtained from mixed solution shows that the measurement are clustered closely around the mean, thus are more reliable.

It was demonstrated that the proposed mixed solution on nanolaminated gold SPR-based sensor had higher sensitivity compared to that with pure urea solution. The enhanced sensor sensitivity is due to the urease enzyme

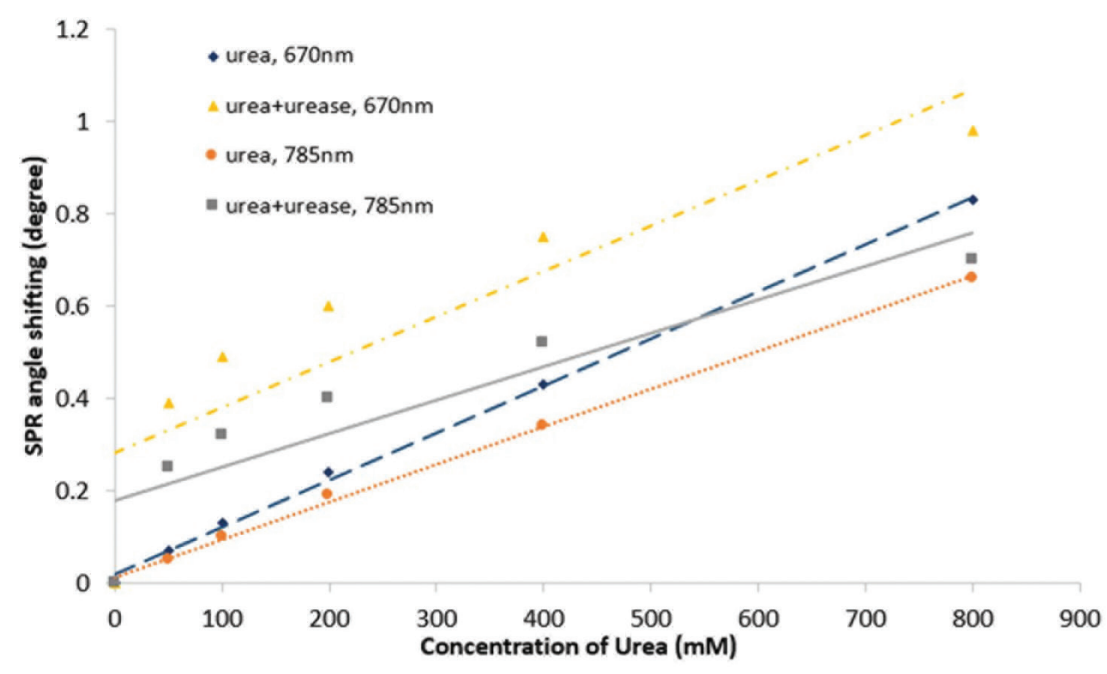

FIGURE 5. A linear relationship between the SPR angle shift of urea and mixed solution with different urea concentration 


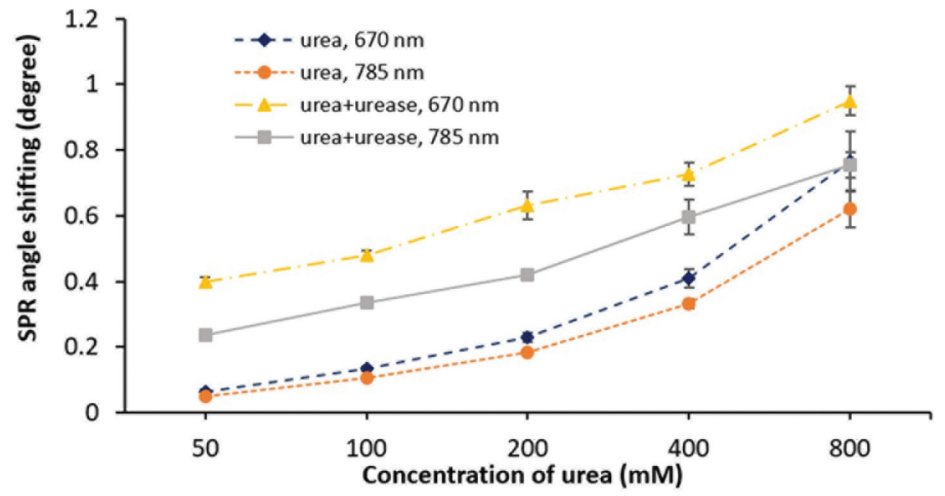

FIGURE 6. Variation of SPR angle shifting with urea concentration of 50, 100, 200, 400 and $800 \mathrm{mM}$ for urea and mixture of urea/urease solution

catalyst activity towards urea molecules that results in an increase in the refractive index near the sensing surface of the SPR sensor. Kretschmann-based SPR sensors with 50 $\mathrm{nm}$-thick nanolaminated gold film for urea detection using mixed solution is a suitable method especially for artificial kidney applications. It is economical and is a label-free detection method showing ease of operation, excellent sensitivity and rapid selection in designing biomolecular sensor subsequently to be deployed in optical fiber-based SPR sensor for portable applications.

\section{CONCLUSION}

In summary, we have successfully executed an investigation on nanolaminated gold film SPR-based sensor using Kretschmann-based SPR sensing. To the best of the our knowledge, this is a novel investigation on the SPR sensitivity of $50 \mathrm{~nm}$-thick nanolaminated gold film towards the different concentration urea in urea/urease mixed solution. Subsequently, the sensorgram, repeatability and linearity of the nanolaminated gold film towards pure urea and mixed solution in various concentration were investigated and analysed. The effect of urease enzyme catalyst activity in the urea solution was found to enhance their molecular bonding to the nanolaminated gold film surface, which increase the sensitivity of the sensor by $457 \%$ compared to a pure urea solution (50 $\mathrm{mM}$ concentration using $670 \mathrm{~nm}$ wavelength). Additional advantages of this sensor are its low cost, flexibility usage of urease enzyme concentration, ease in fabricating nanolaminated thin films and capability of detecting increasing urea concentration.

\section{ACKNOWLEDGEMENTS}

This work was supported by the Ministry of Education (Malaysia) and Universiti Kebangsaan Malaysia using the Higher Institution Centre of Excellence (HiCOE) Grant of AKU-95, National Impact Grant DIP-2016-022 and Research University Grant GUP-2016-062, respectively. Authors would like to thank the Institute of Microengineering and Nanoelectronics (IMEN), Universiti Kebangsaan Malaysia and Public Services Department (JPA) Malaysia for the support.

\section{REFERENCES}

Dhinaa, A.N. \& Palanisamy, P.K. 2010. Optical nonlinearity in measurement of urea and uric acid in blood. Natural Science 2(2): 106-111.

Gan, S.M., Mohamad, N.R., Jamil, N.A., Majlis, B.Y.\& Menon, P.S. 2018. Pengoptimuman sensor resonans plasmon permukaan berdasarkan Kretschmann dengan kaedah Taguchi. Sains Malaysiana 47(10): 2565-2571.

Han, Y.A., Ju, J., Yoon, Y. \& Kim, S.M. 2012. Analysis of urea in human serum using an oblique angle deposited Ag nanorod surface enhanced Raman scattering substrate. Proceedings of the IEEE Conference on Nanotechnology doi:10.1109/ NANO.2012.6321979.

Jamil, N.A.B., Menon, P.S., Mei, G.S., Shaari, S. \& Majlis, B.Y. 2018. Peningkatan kepekaan biosensor urea berasaskan resonans plasmon permukaan dan tatasusunan Kretschmann dengan struktur hibrid Grafin-MoS 2 . Sains Malaysiana 47(5): 1031-1036.

Liedberg, B., Nylander, C. \& Lunström, I. 1983. Surface plasmon resonance for gas detection and biosensing. Sensors and Actuators 4(C): 299-304.

Mahadeva, S.K. \& Kim, J. 2013. Porous tin-oxide-coated regenerated cellulose as disposable and low-cost alternative transducer for urea detection. IEEE Sensors Journal 13(6): 2223-2228.

Menon, P.S., Said, F.A., Gan, S.M., Berhanuddin, D.D., Umar, A.A., Shaari, S. \& Majlis, B.Y. 2018. Urea and creatinine detection on nano- laminated gold thin film using Kretschmann- based surface plasmon resonance biosensor. PLOS ONE 13(7): 1-14.

Premanode, B. \& Toumazou, C. 2007. A novel, low power biosensor for real time monitoring of creatinine and urea in peritoneal dialysis. Sensors and Actuators, B: Chemical 120(2): 732-735.

Said, F.A., Menon, P.S., Rajendran, V., Shaari, S. \& Majlis, B.Y. 2017. Investigation of graphene-on-metal substrates for SPR-based sensor using finite-difference time domain. IET Nanobiotechnology 11(8): 981-986.

Verma, R. \& Gupta, B.D. 2014. Anovel approach for simultaneous sensing of urea and glucose by SPR based optical fiber multianalyte sensor. The Analyst 139(6): 1449-1455. 
Yang, Y.A., Kuo, W.C. \& Lin, C.H. 2014. Enzyme-doped polyester thread coated with PVC membrane for on-site urea and glucose detection on a thread-based microfluidic system. Proceedings of the IEEE International Conference on Micro Electro Mechanical Systems (MEMS). pp. 959-962.

Yang, Z., Liu, X., Zhang, C. \& Liu, B. 2015. Biosensors and bioelectronics a high-performance nonenzymatic piezoelectric sensor based on mo- lecularly imprinted transparent $\mathrm{TiO}_{2}$ film for detection of urea. Biosensors and Bioelectronic 74: 85-90.

P Susthitha Menon*, Fairus Atida Said, Gan Siew Mei, Mohd Ambri Mohamed, Ahmad Rifqi Md Zain, Sahbudin Shaari \& Burhanuddin Yeop Majlis

Institute of Microengineering and Nanoelectronics (IMEN)

Universiti Kebangsaan Malaysia

43600 UKM Bangi, Selangor Darul Ehsan

Malaysia
Ahmad Rifqi Md Zain

Harvard John A Paulson

School of Engineering and Applied Science

Harvard University, Cambridge, MA

United States of America

*Corresponding author; email: susi@ukm.edu.my

Received: 16 July 2018

Accepted: 26 October 2018 